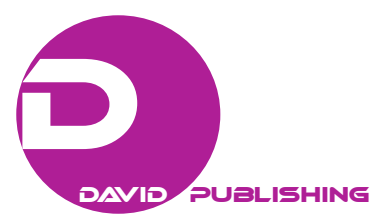

\title{
Tuva, April 1914: Incorporation as a Russian Protectorate
}

\author{
Sureyya Yigit \\ New Vision University, Tbilisi, Georgia
}

\begin{abstract}
Scholarly narratives concerning Tuva becoming a protectorate of Czarist Russia tend to contextualise this action within Russia’s rivalry with China. The 1911 Chinese Revolution provided an opportunity to annex Tuvan territory, culminating in Tuva becoming the final territorial expansion of the Empire before the Bolshevik Revolution. This research showcases that the Tuvan people were intent on much closer relations with newly independent Mongolia. The author argues that the Tuvan people belonging to the Turkic family of nations shared important values with and identified much more closely with Mongolia than Russia due to their common religion: Buddhism. The author stresses the fact that the increasing presence of Russians in Tuva in the mid 19th century resulted in the acknowledgement of two highly unfamiliar cultures and viewpoints. Utilising primary sources this work sheds light on the debates and choices Russia faced concerning Tuva and the opposition maintained by the new Mongol entity intent on unifying under its auspices peoples which were considered very close if not the same. This research highlights the Tuvan predicament as being located in more of a triangular contest than what is usually presented as a bilateral power struggle.
\end{abstract}

Keywords: Tuva, Mongolia, Russia, Buddhism, protectorate

The Turkic world is located in Eurasia and incorporates many nations. One member of the Turkic family is the Tuvans who speak a variation of Turkish but due to historical and religious reasons have been greatly influenced by Mongol culture. Their historical developments have taken place in a geography that has encountered the rising power of the Chinese, Mongols, and the Russians. This article provides an analysis of events concerning bilateral relations between the governments of Russia and Mongolia on what was termed the “Uryankhai issue” (Дацышен, 2017; Spence, 1993; Kaiskii, 2007; Vasilenko, 2017; Kuzmin, 2018).

There are multiple explanations concerning the roots and origins of the Tuvans and their culture (Zeahan, 2017; Bingsheng, 2011; Tumen, 2004; Hai, 1996; Hou, 2014; Glenfield, 2003; Shurkhuu, 2014; Mongush, 2014; Stone, 2012; Jianhua \& Shuguang, 2014; Vainshtein, 1968; Levin, 1963; Kilunovskaya \& Semyonov, 2019; Boeschoten, 1998; Kara, 2018; Alkaya, 2009; Küçük, 2015; Özbek, 2016; Kormuşin, 2001; Koçoğlu-Gündoğdu, 2011; Arikoğlu, 1999; Arıkoğlu \& Borbaanay, 2007; Baran, 2017; Çetintaş, 2008). A central theme found in the academic literature concerns the Tuvans who religiously are closely related to the Mongol people, who are Turkic not solely due to linguistic familiarity, but due to ethnic roots which include and encompass the Yenisei Kyrgyz (Arikoğlu, 1997).

Historically, from 300-200 BC and up to 100-200 AD the current territory of the Tuva was occupied by the Huns. Between the 5th and 8th centuries, the Gokturk and the Uighur states ruled over this land (Kormuşin, 2001). In the 8th century, what could be termed the original or local peoples, namely the Yenisei Kyrgyz, was able to 
establish their organization having gained independence from the Uighurs (Khvichia, 2012). The aforementioned Yenisei Kyrgyz remained sovereign in this territory until the beginning of the 10th century (Mitko, 2019).

Since ancient times, the basic ethnic characteristics-territory, language, culture, and lifestyle - distinguished Tuvans as an ethnic community among other nations. The historical path to creating the sovereign statehood of the Tuva ethos encountered the empire of Genghis Khan and the reign of Altyn Khan (Anaiban, 1998). In 1207, the Tuvan territory was incorporated into the Chingis Khan State (Dongak, 2010). With the elimination of Mongol rule and dynasty in China and the fragmentation of the Mongol State, the Tuvans came under the authority of the Eastern Mongols and the Oyrot (Znamenski, 2014). From the 16th century onwards the Tuvan territories became administered by the Golden Horde being transferred to Chungaria in the 17th century (Glaesser, 1968).

\section{Buddhism}

Similar to many Siberian peoples, the Tuvans also experienced the influence of Mongolian culture due to being in such proximity (Diószegi, 1962). The primary factor which affected the Tuvans and increased this influence was the effect of religion. The originality of the psychological characteristics of the ethnic group can be determined by religion. The influence of shamanism contributed to the formation among Tuvans of a careful attitude to nature, its spiritualization, tolerance for everything that surrounded it (Kenin-Lopsan, 1997). Shamans provided psychotherapeutic help and support to the person, members of their family, and the ethnic group as a whole (Lindquist, 2005). The official adoption of Buddhism in the form of Lamaism occurred in 1753 as Tuvans became subjects of the Manchu State (Пименова, 2013). Buddhism entered the region from Mongolia and the people adopted it as their worldview. Thus, in the 18th century, one can assert that the Tuvans accepted the wholesale belief system of the Mongols, namely Lama Buddhism.

Buddhism did not only have a dominant effect on the Tuvan people but simultaneously acquired national-specific forms depending on the psychological characteristics of the ethnic group. Buddhism greatly enhanced the adoption of Mongol culture. The greater use of religious books written in the Mongol script and the adoption of Mongol written script tremendously increased the influence of the Mongol over the Tuvan peoples. Sat asserts that

before 1920, 1-1.5\% of the Tuvans were literate. The literate people used the Mongolian alphabet of Uighur origin, written from above, and written communication was in Mongolian. The Sin newspaper, whose name was "Unen" at the time of publication in 1925, can be cited as an example of a Mongolian work. (Sat, 1987, p. 104)

From 1756-1757, the Qing Empire divided Tuva into seven khoshuns (Lkhagvasuren, 2012). The Qing Dynasty established a brutal military administrative regime on the territory of Tuva which did not allow Tuvans to leave their khoshun without permission. All the men of Tuva were also required to engage in military service. The long period of the colonial regime developed a special mentality of the Tuvan ethos of protective tendencies (Yaz’kova, 2006). This was pushed further by the practice of self-survival. In general, it can be said that the historical events of the 19th-20th centuries changed the ethnocultural situation in greater Central Asia, though they did not interrupt the ethnic continuity amongst the Turks (Golden, 1992; 1998). At this time, the formation of many modern Turkic ethnic groups was being completed (Micallef \& Svanberg, 1999). To illustrate, among the eastern Turkic ethnic groups, the Yakuts were much better in terms of preserving their language in its original form (Tarabukina, 2015; Robbek, 1998). 
There is, however, one highly significant difference concerning the Tuvan people when compared to the other peoples of Siberia, the vast majority of the Siberian peoples succumbed to Russian influence and administration in the 17th century whereas the Tuva held out and only acquiesced to Russian sovereignty in the 20th century (Bassin, 1999). This unique situation separates the Tuvan people from the other nations which constitute the Russian Federation. It must be recalled that this region witnessed increasing competition between China and Russia during this period. Within this intense competition, the Russian traders who came to trade and settle in the region were used as effective tools of the Czarist policy of imperial enlargement.

\section{Russian Expansion}

The Russians which first migrated to this area were religious believers who were escaping the centralized control of the Orthodox Church (Kon, 2007). Mass Russian migration to the region began only from the beginning of the 19th century onwards. Similar to other migratory flows, the Russians which migrated to this region were traders as well as landless villagers. One particular pull factor the Tuvan territories held concerned the gold mines which attracted the fortune seekers and traders from the 1830s onwards (Sullivan, 1995; Maenchen-Helfen, 1992). By the 1880s the numbers of Russian gold miners had reached more than 450 (Dulov, 1956).

The Chinese Manchu administration despite trying to stem and reverse Russian migration was ultimately unsuccessful in this effort and forced to negotiate with the Russians. One notable turning point is the Peking Treaty of 1860 whereby Russians were given the right to trade in both present-day Mongolia and Uryankhai but forbidden to settle permanently (Tang, 1969). China was too weak to enforce the whole agreement which led to the Russians freely settling in the region despite the inadequate attempts to halt such actions. Thus, Tuva was inaccessible for Russian merchants until the mid 19th century when they became the first to engage in economic activity there. By the 1860s, the Russians had been able to establish 16 commercial enterprises throughout the Tuvan territory (Rodevich, 1910).

The 1870s witnessed greater Russian settlement (Dirin \& Fryer, 2020; Ewing, 1981). The increased use of colonial and exploitative policies which had been successfully implemented throughout Siberia resulted in amplifying tensions between the local Tuvan people and the Russians. The Tuvans desired a halt to the exploitation of the local resources which on occasion did lead to conflict with the settled Russians (Samdan, 2017). The Russians, in turn, petitioned the Czar to send the Imperial Army to stop the attacks perpetrated by the locals. Unable to stem the tide of Russian emigration in the 1870s, permission was granted by China in 1881 to allow permanent settlements (Ewing, 1981; Poppe, 2007).

The Russians were joined in the 1890s by Chinese merchants who began to enter the territory through Mongolia. Their aggressive activities were noted in 1913 by Colonel Popov:

Tuva has been completely ruined and reduced to a state of pauperism by the colossal exactions of the Chinese authorities and officials on the one hand, and by the unscrupulous practices of the Russian traders on the other hand, and in the last ten years especially by the Chinese Tradesmen... The Russian Tradesmen, coarse and cruel, have not hesitated to extort the last sheep for a box of matches given on credit a few years earlier or to grab the best pasture and hay harvests. (Dallin, 2013, pp. 137-142)

The beginning of the 20th century witnessed the beginning of closer interaction of the Tuvan ethnic group with Russia (Sullivan, 1995). The nature of the interaction was quite controversial but played a positive role in the development of the culture of the Tuvan ethnos. The difficulty centred on Tuva facing a different civilizational culture that was completely unfamiliar to it. During this period, the nature of multi-ethnic 
processes in the Tuva region was changing, which were already aimed not at preserving, but at developing the cultural identity of the ethnic group. By 1910 there were as much as 2,000 Russian merchants and colonists residing in Tuva (Popov \& i Mongoliyu, 2015).

Concerning Tuva, the Russian government was divided into two factions whereby one was inclined to take advantage of Chinese weakness and immediately annex Tuva, whose status was unclear. Reference was made to the Russian-Chinese Treaty of Khalkha in 1727 in that there was no clear demarcation of the border and Tuvan territories (Her, 1997). Opposing this view was the Foreign Minister Sazanov who rejected the notion of legal grey areas at a cabinet meeting on 21 November 1911 by focusing on the border agreement of 1864 which recognized the status of Tuva as belonging to China (Dallin, 2013, pp. 137-142).

An important external factor also weighed heavily on Russian minds during this time. Tensions in southeastern Europe were escalating; therefore, it made sense not to unnecessarily antagonise Britain through engaging aggressively with China. The Cabinet finally concluded that

The original diplomatic documents dating back to the eighteenth century, evidently cannot serve as a solid basis for the defence of our claims that the Uryankhai region belongs to Russia. Likewise, the protocol of 1864...apparently vitiates the possibility of declaring our claims to the Trans-Sayan region. (Dallin, 2013, pp. 137-142)

\section{The Tuvan Effects of the 1911 Chinese Revolution}

A vital turning point occurred with the Chinese Revolution of 1911, which encouraged separatist movements and culminated in cases of successful separation from China's autonomy, most notably Outer Mongolia during 1911-1912 (Onon \& Pritchatt, 1989). The Mongolians believed it was natural for Tuva to become part of their territory and began to recruit soldiers from Tuva. Due to the difficult political situation in China after the Revolution of 1911, the former overlord of Tuva and Mongolia was unable to record this development through an international act (Mitter, 2011). It is also necessary to take into account the circumstance that Khalkha-Mongolia, having received the support of the right to exist within the framework of a wide autonomy, as part of the Republic of China, became an independent player in the political arena (Onon \& Pritchatt, 1989). Kobdo, Khalkha, Barga, and the Uryankhai Territory should have been included within Greater Mongolia, which the government of Urga was planning to create (Síma, 1974).

The latter was not of primary importance for Mongolia; however, the political sympathies of a part of the Tuvan elite prompted the Khalkha's top leadership to take active measures aimed at the early adoption of several Tuva khoshuns into their composition. The historic linkage with Mongolia is underlined by Dorzhu and Ondar reiterating that "From the earliest times generic Tuvan tribes were a part of the Mongol khanate, which in turn, since the mid-eighteenth century was dependent on the Qing dynasty of China” (Dorzhu \& Ondar, 2018, p. 489).

Thus, the Chinese Revolution of 1911 witnessed the loss of Manchu authority over Mongolia and the Tuvan territory, the results of which was the increase of Russian migration to the Uryankhai territories. Despite the close relationship with Russians, the Tuvan elite greatly preferred to forge links with the Mongols. Whereas the Tuvan elite considered their fate to be inevitably tied with the Mongols, the Russians had diverging interests and ideas. The Russian Council of Ministers accepted in November 1911 the speedy colonization of the wealthy natural resources contained in the Tuvan territory (Alatalu, 1992).

The declaration of independence of Mongolia in December 1911 led to the rise of the national movement in Uryankhai, which ended in the complete elimination of the Chinese presence in the region (Tachibana, 2014). 
Freed from the influence of China, the Tuvan elite had to decide on the choice of a form of statehood. The following circumstances should have influenced the solution of this problem: A group of oriental Khoshuns led by the Amban-Noyon sought unity with Russia, a group of Khoshuns headed by the Mongosh Buyan-Badyrgy, having lost Chinese support, sympathized with Mongolia (Hoch \& Kopeček, 2019). The active policy of the government of Urga in Tuva and the lack of decisive action on the part of St. Petersburg was determined by the fact that by the end of 1912 most of the khoshuns had passed into Khalkhi citizenship. The determining motive in the national self-determination of Tuvans was the religious unity of Tuva and Mongolia (Walters, 2001).

The Russian diplomatic mission in Peking implored the capital to take advantage of this most opportune situation and annex Tuva. Foreign Minister Sazanov did not share this viewpoint but did relay the suggestion to the Czar. Czar Nicholas II disagreed and wrote "I, on the contrary, am in full agreement with the charge d'affaires in Peking...We must proceed to resolve this business in a more active manner, or else we shall never do ourselves any good along the Chinese border” (Dallin, 2013, pp. 137-142).

Facing a revitalised and autonomous Outer Mongolia legitimately claiming jurisdiction over Tuva, Russia's immediate concern focused on preventing the unification of Tuva with Mongolia. The threat was a real one as not only had Tuva experienced Chinese-Mongolian administration before, but the preference of the Tuvans was to live together with the Mongols under one roof rather than be under Russian or Chinese control.

\section{Protectorate Path}

In January 1912, a congress of Tuvan noyons took place, at which it was decided to declare Uryankhai under the auspices of the Russian State (Alatalu, 1992). In 1913 it was arranged for two Tuvan provinces to appeal to the Czar to incorporate their lands into the Empire. On November 5, 1913, the Russo-Chinese Declaration on the recognition of the autonomy of Outer Mongolia was signed in Beijing (Nakami, 1980). Russia recognized the suzerainty of China over Outer Mongolia (Feng, February 3, 2014). China, recognizing the Russian-Mongolian agreement of 1912, acknowledged Mongolian autonomy and was obliged to refrain from interference in Mongolia's internal affairs (Russo-Chinese Declaration of 1913, n.d.). This declaration provoked a negative reaction in the ruling circles of Mongolia which yearned for including Mongolians beyond the stated border (Гольман, 2013).

As Her underlines, it was on December 16, 1913, when Mongolia notified Russia that it terminated relations with China, and thereby did not recognize the validity of the Sino-Russian declaration recognizing Chinese "suzerainty" over Outer Mongolia (Her, 1997). In turn, with the signing of the Russo-Chinese Declaration on the Mongol issue, the last hope for joining Khalkha disappeared for the Tuvans. According to the agreement, only Khalkha and Western Mongolia entered Outer Mongolia (Friters, 1937).

In December 1913, the governments of Russia and China were handed a note by the Mongolian government, stating that it categorically refused to recognize the Russian-Chinese declaration to bind Mongolia. The note stated that the Mongolian government would insist on such a definition of the borders of the Mongolian state so that all Mongols were included in its composition. Mongolia had "felt betrayed and sent a protest to Beijing saying that the Mongolian government considered 'relations with China severed forever'” (Friters, 1974, p. 174).

The Tsarist government did not immediately decide on the accession of Tuva to the Empire, as Sazonov preferred the option of accepting the territories not as part of the Empire but as a protectorate and was able to convince the Czar of this policy on 11 April 1914 (Dallin, 2013, pp. 137-142). The appeal of the Tuvans provided the legal basis Czar Nicholas II in acquiescing to the memorandum of Foreign Minister Sazonov 
concerning the issue of accepting the population of the five khoshuns of the Uryankhai Territory under Russian patronage (Ширижик, 2017; Shurkhuu, 2014). This became the first step towards establishing an imperial protectorate (Tyva, 1994). The Uryankhai territory was a part of the Mongolian state, and in the period from 1758 to 1912, it was a part of the Qing Empire (D. Z. Iu \& I. O. Iu, 2017). Mongolia did not wish to lose authority over this region and declared the illegality of the declaration of a protectorate of Russia over Tuva (Humphrey, 2015). Interethnic relations between Tuvans and Russians began to deteriorate.

The fear of reunification and close contact between the Tuvans and Mongols remained despite this recent measure. To prevent close contact as much as possible Russia engineered a decision by the Tuvan leader to agree to no deliberations with Mongolia or any other outside power without Russian involvement. On 4 July 1914, the Tuvan leader wrote to the Czar that

I oblige myself to conduct all negotiations through the representative of the Russian Government resulting in Uryankhai and to submit to his decision all controversies and misunderstandings which may arise among the various khoshuns of Uryankhai. At the same time, I most humbly beg to leave to our Uryankhai population their customs, the Buddhist religion, which they practice, their way of life, self-government, ranks and nomad camps, permitting no special alterations, which would tend towards a loss of power. (Dallin, 2013, pp. 137-142)

Less than a month later the First World War erupted in Europe and greater Central Asia lost all importance in European capitals. Russia began to extend its influence and surveillance in Tuva applying the Russian civil and criminal codes in 1915, rejecting permission a year later to Mongolia for their agents to enter Tuva (Dallin, 2013, pp. 137-142). The Cossacks were sent to Tuva who arrested Tuvans with anti-Russian sentiments and Russian immigration and resettlement quickly gathered pace.

After the announcement of the Russian protectorate over the isolated Uryankhai Territory, it was drawn closer into the orbit of the Russian economy. At this time, the first city was also founded, named as Belotsarsk-later to be changed to Khem-Beldyr in 1917 (Bondarenko, 2009; Humphrey, 2015). From 1912 until 1918 the Russian population in Tuva increased by 300\% (Chevalier, 2010). According to the 1919 census, the total population of the region amounted to 60 thousand people of which 48,000 were Tuvan, with Russians and other nationalities comprising the rest (Dallin, 2013, pp. 137-142).

Since ancient times Tuva had been "known as a destitute, barbarian and shamanic backwater...a political no-man’s land” (Pedersen, 2011, p. 10). Pedersen further noted that the region could also be seen as a "political everyman's land”, since Russia and China ruled over the territory by offering protection and extracting taxes, at times simultaneously (Pedersen, 2011, p. 12). In the final analysis, 1914 witnessed a further example of Russian expansionism into the ancient Turkic lands of greater Central Asia. Whilst the Tuvans were encouraged by the successful path to independence by Mongolia and its leadership wished to form closer ties with their religious brethren, they had to endure the exchange of one overlord for another.

\section{References}

Alatalu, T. (1992). Tuva—a state reawakens. Soviet Studies, 44(5), 881-895.

Alkaya, E. (2009). Sibirya Tatar Türkçesiyle Güney Sibirya (Altay, Hakas, Tuva) Türk Lehçeleri Arasindaki Ortak Unsurlar. Electronic Turkish Studies, 4(8), 273-321.

Anaiban, Z. (1998). The Republic of Tuva: A model of ethnological monitoring. Anthropology \& Archaeology of Eurasia, 37(3), 13-91.

Arikoğlu, E. (1997). Tuva Cumhuriyeti ve Tuva Türkleri. Yeni Türkiye (Türk Dünyası Özel Sayısı), May - June, II(16), 1561-1569. 
Arikoğlu, E. (1999). Tuva Türkçesinin Tarihi Gelişimi ve Üzerinde Yapılan Çalışmalar. Türk Dünyası Dil ve Edebiyat Dergisi, (4). Retrieved from https://dergipark.org.tr/tr/pub/tdded/issue/12718/154887

Arıkoğlu, E., \& Borbaanay, B. (2007). Tuva destanları (Vol. 887). Ankara: Türk Dil Kurumu.

Baran, B. (2017). Nikolay Fedoroviç Katavov’un Tuva Türkleri ve Tuva Türkçesi Araştırmalarına Katkısı. MTAD, 14(4), 59-69.

Bassin, M. (1999). Imperial visions: Nationalist imagination and geographical expansion in the Russian Far East, $1840-1865$

(Vol. 29). Cambridge: Cambridge University Press.

Bingsheng, G. U. A. N. (2011). Multidimensional conflicts: Layered differences in the construction of the Tuva in China. Journal of Ethnology, (5), 4.

Boeschoten, H. (1998). The speakers of Turkic languages. In The Turkic languages (pp. 1-15). New York: Routledge.

Bondarenko, T. A. (2009). The foundation history of the city in the center of Asia: To the 95th anniversary of Belotsarsk-Uryankhaysk-Krasnyi-Kyzyl. The New Research of Tuva, (4), 109-119.

Çetintaş, M. (2008). Tuva Destanları. Türk Dünyası Dil ve Edebiyat Dergisi, (25), 109-113.

Chevalier, J. F. (2010). Bilingualism and literacy in the Republic of Tyva. Sibirica, 9(1), 1-22.

Дацышен, В. Г. (2017). Революция 1917 г. в Туве. Новые исследования Tувы, (4), 4-24.

Dallin, D. J. (1949). The rise of Russia in Asia. New Haven: Yale University Press.

Dirin, D. A., \& Fryer, P. (2020). The Sayan borderlands: Tuva's ethnocultural landscapes in changing natural and socio-cultural environments. Geography, Environment, Sustainability, 13(1), 29-36.

Diószegi, V. (1962). Tuva shamanism: Intraethnic differences and interethnic analogies. Acta Ethnographica, 11(1-2), 143-190.

Dongak, V. S. (2010). Problems of the history and modern situation of the Tuva-Mongol relations. Новые исследования Tувы, (1), 188-205.

Dorzhu, Z., \& Ondar, E. (2018). Peculiarities of the formation of parliamentarism in Tuva peoples' republic (1921-1944). Astra Salvensis-revista de istorie si cultura, VI(Suppelement 1), 485-499.

Dulov, V. I. (1956). Sotsial'no-ekonomicheskaia istoriia Tuvy. XIX-nachalo XX $v$ [The socio-economic history of Tuva. XIX — early XX centuries]. Moscow: Akademia Nauk SSSR Publ.

Ewing, T. E. (1981). The forgotten frontier: South Siberia (Tuva) in Chinese and Russian history, 1600-1920. Central Asiatic Journal, 25(3/4), 174-212.

Feng, J. Y. (February 3, 2014). The 1911 Revolution and the Frontier: The "political game” and "state-building” in Outer Mongolia during the 1911 Revolution. The Asia-Pacific Journal, 12(5), No. 3.

Friters, G. M. (1937). The prelude to outer Mongolian independence. Pacific Affairs, 10(2), 168-189.

Friters, G. M. (1974). Outer Mongolia and its international position. New York: Octagon Books repairing.

Glaesser, G. (1968). Kočevniki vostočnoj Evropy pod vlast'ju zolotoordynskih hanov-Arheologičeskie pamjatniki (The nomads of Eastern Europe under the rule of the Khans of the golden horde-archaeological documents). East and West, 18(3/4), 370-375.

Glenfield, A. (2003). The pearl of Tuva: Authenticity and Tuvan khorekteer (throat singing). MUSI Cultures, 30, 32-46.

Golden, P. B. (1992). An introduction to the history of the Turkic peoples. Ethnogenesis and state-formation in medieval and early modern Eurasia and the Middle East. Wiesbaden: O. Harrassowitz.

Golden, P. B. (1998). The Turkic peoples: A historical sketch. The Turkic Languages, 16, 29.

Гольман, М. И. (2013). Западные авторы об отношениях России и Монголии. In Россия и Монголия на рубеже XIX-XX веков: Экономика, дипломатия, культура (pp. 222-227). [Zapadnyye avtory ob otnosheniyakh Rossii i Mongolii. In Rossiya i Mongoliya na rubezhe XIX-XX vekov: Ekonomika, diplomatiya, kul'tura (pp. 222-227). Western authors on relations between Russia and Mongolia. In Russia and Mongolia at the turn of the 19th-20th centuries: Economics, diplomacy, culture (pp. 222-227)]. Moscow: Russian Academy of Science.

Hai, T. Q. (1996). Tuva-echoes from the spirit world. Ethnic Series, Pan 2013 CD.

Her, E. (1997). The “Great Game”: Mongolia between Russia and China. Mongolian Journal of International Affairs, 4, 62-71.

Hoch, T., \& Kopeček, V. (Eds.). (2019). De Facto States in Eurasia. New York: Routledge.

Hou, Y. (2014). The analysis of current situation of Tuva people in China. новые исследования тувы, (1), 96-103.

Humphrey, C. (2015). Is Zomia a useful idea for Inner Asia? Mongolian Journal of Anthropology, Archaeology and Ethnology, $8(1), 92-107$.

Iu, D. Z., \& Iu, I. O. (2017). Political repressions in the Tuva people's Republic: Was it possible to avoid them? Журнал Сибирского федерального университета. Гуманитарные науки, 10(7), 957-964.

Jianhua, Y., \& Shuguang, B. (2014). Early nomadic cultures in Tuva and Altai regions in Russia. The Western Regions Studies, (2), 9. 
Kaiskii, M. (2007). Uriankhaiskii vopros [The Uriankhai issue]. Uriankhai. Tyva depter [Uriankhai. Tuvan notebook]/comp. by SK Shoigu. Moscow, Slovo, 5, 552-563.

Kara, D. S. (2018). The formation of modern Turkic "Ethnic” groups in central and inner Asia. The Hungarian Historical Review, 7(1), 98-110.

Kenin-Lopsan, M. B. (1997). Tuvan shamanic folklore. In Shamanic worlds: Rituals and lore of Siberia and Central Asia (pp. 110-152). Armonk, New York: M. E. Sharpe.

Khvichia, J. A. (2012). Formation of Uyghur settlements in the territory of contemporary Tuva in the early 18-mid 19 centuries. Журнал Сибирского федерального университета. Серия: Гуманитарные науки, 5(5), 719-728.

Kilunovskaya, M., \& Semyonov, V. (2019). Ancient cultures of Tuva and its environment in 4th-1st Millennia BC. Oriental Courier, (1-2), 30-61.

Koçoğlu-Gündoğdu, V. (2011). Türk dilinde yönelme ve bulunma hali ile ilgili birkaç ayrinti-tuva türkçesi örneği. Turkish Studies, $6,1$.

Kon, F. Y. (2007). Usinskii krai [Usinsk region]. Uriankhai. Tyva depter [Uriankhai. A Tuvan notebook]/comp. by SK Shoigu. Moscow, Slovo, 4, 262-347.

Kormuşin, İ. V. (2001). Kuzey Tuva Ögök-Turan Vadisindeki Göktürk Anıtlarının Bazı Özellikleri. Türk Dili Araştırmaları Yılliğt-Belleten, 48, 257-261.

Küçük, M. A. (2015). Altay ve Güney Sibirya Bölgesindeki Türk Topluluklarının Dini inanışları. Dini Araştırmalar, 8(23), 191-218.

Kuzmin, S. L. (2018). The Uriankhai issue and Mongolia-Tuva relations in the early the 20th century. Retrieved from https://doi.org/10.22162/2619-0990-2018-37-3-2-14

Levin, M. G. (1963). Ethnic origins of the peoples of northeastern Asia (Vol. 3). Toronto: University of Toronto Press.

Lindquist, G. (2005). Healers, leaders and entrepreneurs: Shamanic revival in southern Siberia. Culture and Religion, 6(2), 263-285.

Lkhagvasuren, I. (2012). The administrative structure. Senri Ethnological Reports, 101, 5-14.

Maenchen-Helfen, O. (1992). Journey to Tuva (No. 5). Los Angeles: Ethnographic Press.

Micallef, R., \& Svanberg, I. (1999). Turkic Central Asia. In Islam Outside the Arab world (pp. 149-165). NY: Routledge.

Mitko, O. A. (2019). Inscriptions on medieval broadswords and Sabers Yenisei Kyrgyz. Stratum Plus, (5), $233-242$.

Mitter, R. (2011). 1911: The unanchored Chinese revolution. The China Quarterly, 208, 1009-1020.

Mongush, M. V. (2014). Tuvans outside of Tuva: The problem of ethnic self-conservation. Senri Ethnological Studies, 86, 197-213.

Nakami, T. (1980). On the Russo-Chinese Declaration of November 5, 1913: The emergence of the Republic of China and the Mongol problems. International Relations, 66, 109-127.

Пименова, К. (2013). “Вертикаль шаманской власти”: Использование политического дискурса в постсоветском тувинском шаманизме. Laboratorium: Журнал социальных исследований, 5(1), 187-192.

Onon, U., \& Pritchatt, D. (1989). Asia’s first modern revolution: Mongolia proclaims its independence in 1911. Leiden: Brill.

Özbek, E. E. (2016). Tuva destanlarının söz varlığı. Retrieved from https://hdl.handle.net/20.500.12462/3125

Pedersen, M. A. (2011). Not quite shamans: Spirit worlds and political lives in northern Mongolia. Ithaca, New York: Cornell University Press.

Popov, V. L., \& i Mongoliyu, C. S. (2015). Through Sayan Mountains and Mongolia. YpaHxaM. Tyva depter. The anthology of a scientific and educational thought of the ancient Tuva earth and its monks, about Uryankhaye-Tannu-Tuva, the uryankhaytsakh-Tuvinians, about antiquities of Tuva. 7, 318-319.

Poppe, E. (2007). A hotspot of intergroup relations: Russians and Tuvans in Tuva. In Culture and conflict (pp. 325-344). Amsterdam: Amsterdam University Press.

Robbek, V. (1998). Language situation in the Sakha Republic (Yakutia). In Bicultural education in the North: Ways of preserving and enhancing indigenous peoples' languages and traditional knowledge (pp. 113-122). Münster: Waxmann Verlag.

Rodevich, V. (1910). Ocherk Uriankhaiskogo kraia. Uriankhai. Tyva depter: Antologiia nauchnoi i prosvetitel’skoi mysli o drevnei tuvinskoi zemle i ee nasel'nikakh, ob Uriankhae-Tanu-Tuve, uriankhaitsakh-tuvintsakh, o drevnostiakh Tuvy, comp. SK Shoigu. Moscow, Slovo/Slovo, 3, 344-541.

Russo-Chinese Declaration of 1913. (n.d.). The Great Soviet encyclopedia, 3rd edition (1970-1979). Retrieved July 82020 from https://encyclopedia2.thefreedictionary.com/Russo-Chinese+Declaration+of+1913

Sat, S. Ch. (1987). Tyva dialektologia [The dialectology of Tuvan language]. Kyzyl, TyvNYCh. 
Samdan, A. A. (2017). The Russo-Tuvan conflict of 1908. Retrieved from https://doi.org/10.22162/2075-7794-2017-31-3-27-35 Shurkhuu, D. (2014). Similarities and differences between Mongolia and Tuva in the evolution of bilateral ties. Senri Ethnological Studies, 86, 127-144.

Síma, J. (1974). On the character of the so-called pan-Mongol movement after 1911. Archív Orientální, 42, 97-119.

Spence, R. B. (1993). White against red in Uriankhai: Revolution and civil war on Russia’s Asiatic frontier, $1918-1921$. Revolutionary Russia, 6(1), 97-120.

Stone, E. A. (2012). Genuine Tuvan: Producing authenticity in the Republic of Tuva (Doctoral dissertation, UT, 2012).

Sullivan, S. (1995). Interethnic relations in post-Soviet Tuva. Ethnic and Racial Studies, 18(1), 64-88.

Tachibana, M. (2014). The 1911 revolution and “Mongolia”: Independence, constitutional monarchy, or Republic. Journal of Contemporary East Asia Studies, 3(1), 69-90.

Tang, P. S. (1969). Sino-Soviet territorial disputes: Past and present. Russian Review, 28(4), 403-415.

Tarabukina, U. P. (2015). The development of native languages in educational institutions in the conditions of the dispersed indigenous small-numbered peoples in the North, Siberia and the Russian Far East, in the Republic of Sakha (Yakutia) (on the example of the even language). Journal of Siberian Federal University, Humanities \& Social Sciences, 6(8), 1111-1120.

Tumen, D. (2004). Linguistic, cultural and morphological characteristics of Mongolian populations. Senri Ethnological Studies, 66, 309-324.

Tyva. (1994). Ustanovlenie pokrovitel'stva Rossii nad Tuvoy v 1914 godu [The establishment of the Russian protection of Tuva in 1914]. Kyzyl.

Vainshtein, S. I. (1968). Some questions on the history of ancient Turkic culture: (In connection with archeological research in Tuva). Soviet Anthropology and Archeology, 6(4), 3-24.

Vasilenko, V. A. (2017). "Uriankhai issue” in foreign policy of Russia in early 20th century and the problem of foreign states'participation in it. RUDN Journal of Russian History, 16(4), 641-655.

Walters, P. (2001). Religion in Tuva: Restoration or innovation? Religion, State \& Society, 29(1), 23-38.

Ширижик, В. М. (2017). Правовые основы протектората урянхайского края со стороны российской империи в начале хх в. Вестн. Том. гос. ун-та. Право, (25). doi:10.17223/22253513/25/1

Yaz'kova, A. A. (2006). Russia and its minorities: An overview of existing and potential ethno-political conflicts. Innovation, 19(3-4), 273-282.

Zeahan, L. K. (2017). Contemporary youth identity in the Republic of Tuva, Russia. Новые исследования Tувы, (3), 49-65.

Znamenski, A. A. (2014). Power for the powerless: Oirot/Amursana prophecy in Altai and Western Mongolia, 1890s-1920s. Études mongoles et sibériennes, centrasiatiques et tibétaines, (45), 1-28. 